by Dr. Paul E. Klopsteg, at present the assistant director for mathematical, physical and engineering sciences of the Foundation, and his place is being taken by Dr. Raymond J. Seeger, the programmo director for physical sciences in the Foundation. In his new appointment, Dr. Klopsteg will be responsible for assisting the director and the deputy director of the Foundation in following closely the development of relationships with universities and with other Federal agencies; he will also handle special assignments of importance to the scientific programmes of the Foundation. Dr. Klopsteg is a graduate of the University of Minnesota, and in 1916 he gained there his Ph.D. in physics. His professional career has been devoted to the administration of research, and before the Second World War he was president of the Central Scientific Co. During the War he served with the Office of Scientific Research and Development as chief of Division 17, Physics and Special Devices, of the National Defense Research Committee, which developed important equipment. and devices for war-time use. Later he was assistant chief of the Office of Field Service, which organized and directed the assignment of scientific consultants to the various theatres of war, and in this capacity he served in Australia and New Guinea as chief of the Research Division, General Headquarters, Southwest Pacific. Dr. Klopsteg has been chairman of the board of governors of the Argonne National Laboratory and is chairman of the Committee on Artificial Limbs of the National Research Council. He is at present on leave of absence from his post as professor of applied science and director of research of the Northwestern Technological Institute, Fvanston, Ill.

International Association for the Exchange of Students for Technical Experience

THE fifth annual report of the International Association for the Exchange of Students for Technical Experience (pp. 56; from the secretary, J. Newby, at the Imperial College of Science and Technology, London, S.W.7) records continued progress both numerically and geographically: 3,493 students were sent abroad during 1952, an increase of 1,060 over the previous year. Yugoslavia joined the Association in January 1952, and the Saar and Turkey were represented at the conference of organizer's. One large company with international interests selected in 1952 twelve undergraduate students for nomination to its overseas connexions and received twelve students in Great Britain selected by its overseas counterpart. Places available abroad for students of business administration and commerce increased to 112 as compared with 35 in 1951. More students were accepted than were sent in the following countries (numbers shown in brackets): Sweden (547), Great Britain (114), United States (47), Switzerland (37) and Spain (2). Of countries sending more students than they accept, Austria (161), Germany (148), Netherlands (113), Finland (94), Denmark (93) and France (51) show the largest excesses.

Since the establishment of the Association in 1948, somo 1,440 industrial and other organizations have received foreign students under the scheme; it is estimated that during the summer of 1952 international industry and commerce contributed more than $£ 161,000$ to the Association's programme. The report includes an analysis of industries participating in the exchange and also of the subjects which participating students were studying. A list of institutions and firms taking part in the scheme is included under each country, and a supplement gives further details of exchanges in which Great Britain participated in 1952, when 488 students were sent abroad and 602 foreign students were received and placed. Travelling arrangements appear to require improvement, but relations between the students and other workers were entirely satisfactory, and an interim evaluation of the reports received on British students indicates that 1952 has been the best year both in the numbers sent abroad and in the service given.

\section{International Trade in Agricultural Machinery}

Technically there is seope for much greater use of agricultural machinery, according to a report issued by the Commonwealth Economic Committee, "A Survey of the Trade in Agricultural Machinery" (No. 36 ; pp. 174. London: H.M.S.O., 1952. 7s. 6d.). Rises in the prices of agricultural machinery have been considerably less than those of the principal agricultural commodities, while the urge for greater agricultural production together with widespread increases in the cost of labour should combine to increase the demand for mechanization. Figures relating to world exports of agricultural machinery show that values rose from £25 million in 1938 to $£ 300$ million in 1951. In the post-war period, the United Kingdom has become the second largest manufacturer of tractors in the world, although she is still greatly outdistanced by the United States, where the production is four and a half times as great. The report shows that recent developments have been directed towards reducing manual labour on farms, or mechanizing processes which call for seasonal peaks in labour. To reduce labour costs, balers, loaders and handling gear, electric fences and dung spreaders are being increasingly used, while to decrease the need for casual labour, root harvesters in Europe, sugar-cane harvesters in Australia and cotton harvesters in the United States are being adopted. An important aspect of development has been the adaptation of standard implements to new tasks as, for example, the application of rotary cultivators and combine harvesters to crops of irrigated rice in India.

\section{Scientific Methods in the National Gallery Lab- oratory}

As article on "Scientific Method and the Art Gallery", by Mr. F. I. G. Rawlins and Dr. A. E. Werner, of the National Gallery Laboratory, London, has been published in Science Progress (90, No. 160), in which the authors review developments at the Laboratory since 1939 and show how the application of science has aided the care of pictures. Studies in the effects of temperature and humidity changes and the introduction of air-conditioning are recorded. Recent work in the use of X-rays, ultra-violet and infra-red rays in the examination of works of art is discussed, and some details are given of chemical and physical techniques now used in the treatment of pictures.

\section{Studies in Conservation : Journal of the International Institute for the Conservation of Museum Objects}

THE appearance of a new periodical is in these days an event of prime importance, and especially if that periodical may interest comparatively few 